\title{
Interpreting Qardhul Hasan Between Business and Islamic Corporate Social Responsibility
}

\author{
Sulis Rochayatun ${ }^{1 *}$ Muchammad Zaky Sayugo ${ }^{2}$ \\ ${ }^{1,2}$ Faculty of Economy, Maulana Malik Ibrahim State Islamic University \\ "Corresponding author Email: sulis@uin-malang.ac.id.
}

\begin{abstract}
One of financing programs in Islamic Financial Institutions which is based on mutual assistance is Qardhul Hasan. In Islamic Financial Institutions, one the program in corporate sosial responsibility is helping the poor by providing loan facilities that are free from interest practices. This study aims to determine how the application of the Qardhul Hasan contract to the BMT Wagir Branch. The research is qualitative method using intepretatif paradigm. The study using observation, in depth interview with leader, staff and customer. The result show that BMT Maslahah Wagir Malang implemented the Qardhul Hasan program as one of the Islamic Corporate Social Responsibility programs. Qardhul Hasan Financing in BMT Maslalah only has a percentage of $2 \%$ of other financing issued by BMT, then from these results, it can be concluded that this Qardhul Hasan financing was issued by BMT Maslahah Wagir Malang, not in the context of business whose output is profit/profit, but the Qardhul Hasan financing was issued solely for the Corporate Social Responsibility program.
\end{abstract}

Keywords: Qardhul Hasan, Business, Islamic Corporate Social Responsibility

\section{INTRODUCTION}

In the globalization era, the development of Islamic Financial Institutions practices must be able to adapt to the conventional economy which has long dominated life among the people, including Indonesia. Qardhul Hasan financing is the most unique product and in Islamic Law, it is highly recommended to do so. Qardhul Hasan is a loan in the form of fund financing according to the agreement to the customer provided that the customer is only required to return the principal of the loan he received at the agreed time, either in installments or in cash. Qardh's reference is Fatwa DSN-MUI No.19 / DSN-MUI / IV / 2000 concerning Qardh. [1]. Qardhul Hasan is, one of the products in financing Islamic financial institutions without remuneration and the financing based on mutual cooperation. This product is rolled out to distribute zakat, infaq, and sadaqah funds for employees and funds obtained from external and internal that are collected for the benefit of the people. Qardhul Hasan is very helpful to people who need business capital to start or develop an existing business without having to think about remuneration for the financing he receives. This Loan does not require the provision of benefits from the customer, but if the customer wants to give more than the principal of the loan it is also allowed as long as there is no agreement at the start. The target customers for this loan are people who are economically in the lower class. If the customer is in a condition where it is not possible to return the loan, the Islamic Financial Institution will not collect the loan money back [2].

In Islamic banking, many have decided not to continue the Qardhul Hasan financing contract program, because for loan repayments they often get stuck in the middle of the road and some even do not return them at all. This is because the loan money is not used for empowerment, for example for business capital, but the loan money is used for life necessities only. Banks may remove this program because there is no profit in its implementation. Meanwhile, at BMT Maslahah, Wagir Branch Malang, since 2014 the Qardhul Hasan program has been running as it should. This 
is an interesting phenomenon to be investigated further. The Sharia Financial Institution which is currently experiencing rapid development is the Maslahah BMT. This institution is a non-bank Sharia Financial Institution that carries a vision of the development of the community's economy based on Islamic sharia and the realization of taawun in goodness and piety in the socio-economic field. As well as carrying out the mission to implement Islamic sharia society in economic activities, carry out cultural economic activities that are Shiddiq (honest), Amanah (trust), Tabligh (communicative), Fathanah (professional), and instill understanding in society that the sharia system in the economic field is easy, fair and maslahah [3].

Qardhul Hasan's financing at the BMT Maslahah, Wagir Malang Branch is intended for people who sell in the local market as well as residents or neighbors of BMT Troubled employees but prioritized for people who routinely save every day at BMT Maslahah Wagir branch. Qardhul Hasan in previous research conducted by [4] and [5] shows that the existence of Qardhul Hasan financing can prosper the social community in the environment around Islamic banking in Indonesia. While many conventional banks have not implemented the Qardhul Hasan contract because a lot of financing has turned into bad credit, BMT Maslahah Wagir Branch still implements Qardhul Hasan.

\section{LITERATURE REVIEW}

\subsection{Qardhul Hasan}

Al-Qardh is the gift of assets to others that can be collected or asked for back, or as a loan without expecting anything in return. The Qardh covenant is meant to be gentle towards fellow human beings, to help each other. Al-Qardh in the LKS is a loan agreement (distribution of funds) to the customer provided that the customer is required to return the funds received to the Sharia Financial Institution (LKS) at the time agreed between the customer and the LKS.[6]. According to the Shara 'Law, Qardh is a loan of money or capital that someone gives to another party, where the loan is used for business or running a certain business. The borrower is obliged to return the loan by the amount borrowed without depending on the profit or loss of the business he is running. Qardh loans also have no interest, because the principle in this qardh is to help [7].

The word hasan can also be interpreted as kindness. Qardhul Hasan is a type of loan given to parties who really need it in certain period without obligation to pay interest or profit. The recipient of Qardhul Hasan is only obliged to pay off the principal amount without being required to provide any additional. However, the loan recipient may, in its sole discretion, pay more than the money borrowed as a token of gratitude for the loan. But this must not be agreed upon in advance. [8]. The Qardhul Hasan contract is a contract or agreement in the activity of channeling funds in the form of loan money without any compensation with the obligation of the borrower to return the loan at principle once or in installments in certain period of time. Give a loan of money to someone, with the agreement that the person will pay the same as what was borrowed. For example, borrow Rp. 100,000 then paid 100,000 but can also be paid in installments. The Qardhul Hasan contract is a loan agreement without taking profit or is called a benevolence fund which is social financing for the Islamic Financial Institution (LKS) and the customer (Muqtaridh) is obliged to return the principal received at the time agreed between the customer and the LKS.

In Qardhul Hasan financing, if the customer cannot return the loan which isi part or all of its obligations at the agreed time and the LKS has confirmed his inability, the LKS can : extend the repayment period or write off part or all of its obligations. Whereas in the event that a customer cannot fulfill its obligations, the LKS can impose sanctions on the customer. The sanctions imposed on customers as intended can be in the form of fines and are not limited to the sale of collateral. If the collateral is insufficient, the customer still has to fulfill his obligations in full. The source of AlQardh funds can come from several sources, both internal and external, namely: the share of the capital of the Islamic Financial Institution, the profits of the Sharia Financial Institution that are set aside. Other institutions or individuals entrusting their infaq to Sharia Financial Institutions. The source of Al-Qardh funds comes from internal and external funds, Qardh's internal sources of funds come from capital and profits which can be used for commercial purposes, as a complementary product. However, these internal funds can also be lent to Qardh which is a benevolent loan, to help customers financially quickly and in short term. Meanwhile, external funds from Qardh can come from infaq, shadaqah, and non-halal sources of funds used for Qardh which are benevolent and not used for commercial Qardh. (Muljono, 


\subsection{Business and Islamic Corporate Social Responsibility}

Each company will certainly do various ways to improve the company's existence and become a Good Business company. One way is through a Corporate Social Responsibility (CSR) activity program. CSR is a concept that an organization has a wrong stakeholder, which includes consumers, employees, shareholders, and the environment in all aspects of company operations that include environmental, social, and economic aspects. So basically CSR activities are a form of corporate responsibility to the community which is also a means to build a reputation and increase the company's superiority in a competition [9].

The Corporate Social Responsibility program is a form of investment for companies for the growth and development of the company, which in its activities is no longer considered a means of cost but as a means of making profits. CSR can be said as a form of the company's real contribution to society in realizing sustainable growth and development of the company. In addition, CSR should also be a means to build sustainable partnerships with all stakeholders in realizing the company's goals as well as strengthening the relationship between the two. Because partnerships should indeed be fostered in order to create a positive commitment towards continuity of development and sustainable development [10].

The Republic of Indonesia Government Law No. 40 of 2007 concerning Limited Liability Companies Article 1 paragraph (3) states that CSR is the company's commitment to participate in sustainable economic development in order to improve the quality of life and the environment that is beneficial for the company, community, and society in general. Islamic concern for business profits does not neglect the moral aspects of achieving these profits. This shows that in Islam there is a very close relationship between economics and morals, both of which cannot be separated.

Islamic Corporate Social Responsibility comes from a core principle in the Quran. The top three basic principles for implementing the Islamic Corporate Social Responsibility program are the human audience on earth, a responsibility to God, and the obligation to mankind to carry out better and stay away from prohibitions. The I-CSR concept is based on a relationship of responsibility to Allah SWT, to humans, and responsibility to the environment. Allah SWT has ordered humans to obey Him and as a form of obedience to Allah SWT is to ensure the preservation of human life and the natural environment. So that the human being on earth has two tasks, namely to be a servant who is obedient to Allah SWT and a just caliph. The relationship between these two main tasks cannot be ignored between one to another [11].

The concept of Corporate Social Responsibility (CSR) according to Islam or Islamic Corporate Social Responsibility is different from CSR according to the West. Islamic Corporate Social Responsibility in Islam is built on the basis of Tasawwur and an epistemology that is different from CSR in the West. Tasawwur and ICSR epistemology is based on Al-Quran and Hadith / Assunnah. Both of them become the main reference for the formation CSR concept and criteria. Meanwhile, Western Corporate Social Responsibility is based on the perspective of western society that only uses rationality and is also influenced by Christian and cultural beliefs that develop in the West[2]. ICSR uses 38 items which are benchmarks for the implementation of social performance in Islamic banking which contains a compilation of standard items set by AAOIFI (Accounting and Auditing Organization for Islamic Financial Institutions). The 38 items are grouped into 6 categories, each category consists of several disclosure items, which add up to 38 items, as follows:

1. Finance and Investment : Disclosure of Riba Activities, Gharar Disclosure, Zakat, Bad Debt Elimination, Current Value Balance, Value Added Statement.

2. Product and Services : Green Products, Halal Product Status, Product Quality, Customer Complaints.

3. Employee : Nature of Work, Education and Training, Equal Opportunity, Employee Engagement, Health and Safety, Work Environment, Other Specialized Jobs. Sponsoring Public Health.

4. Community : Sadaqah, Waqaf, Qard Hasan, Employee Volunteers, Scholarships, Job Graduates, Underprivilage Community, Youth Development.

5. Environment : Environmental Conservation, Endangered Wildlife, 
Pollution, Education,

Environmental Audit, Policy.

6. Corporate Governance : Sharia Compliance Status, Ownership Structure, Bod, Declaration of Prohibited Activities, AntiCorruption Policy.

\section{RESEARCH METHOD}

\subsection{Types and Research Paradigms}

This research is a type of qualitative research that describes a real picture of the phenomena that occur in the implementation of Qardhul Hasan financing at BMT Maslalah Wagir Malang. Qualitative research is intended to understand the phenomena of research subjects experience such as behavior, perception, motivation, action, etc. holistically and by means of descriptions in the form of words and language in a special natural context by using various scientific methods[12]. The paradigm used is an interpretive paradigm that aims to obtain a subjective understanding "as is" of an ongoing process [13]. The approach method used to express meaning is phenomenology, which is to describe and explain how the participant understand about Qardhul Hasan financing contract in the context of business and Islamic Corporate Social Responsibility in achieving it. [14] defines phenomenology as a study that describes the object of a concept or a phenomenon.

\subsection{Sites, Informants, and Data Collection Methods}

The site of this research is BMT Maslahah Wagir Malang. The object that is analyzed is the understanding of the parties involved regarding the implementation of Qardhul Hasan financing. . The selected informants are individuals who are directly involved, understand, and can provide information about the implementation of Qardhul Hasan Corporate Social Responsibility financing at BMT Maslahah Wagir Malang. The informants in this study were the leaders of BMT Maslahah, BMT Maslahah employees, Qardhul Hasan BMT customers, the community. The data collection method used was in-depth interviews with informants which were conducted for 5 months, namely August - December 2019. The interviews were conducted in an unstructured and informal manner in various situations. Documentation is used to reveal the social reality that occurs in a document. The data analysis technique used refers to [15] which divides into four stages, namely: (1) describing phenomena, (2) identifying themes, (3) developing noetic/nematic correlates, and (4) abstracting the essence or universals of noetic/nematic correlates.

\section{RESULTS AND DISCUSSION}

\subsection{Qardhul Hasan financing at BMT Maslahah}

Financing Qardhul Hasan at BMT Maslahah Wagir branch started from public anxiety that previously borrowed money from renter or loan sharks where people had to bear the burden of high interest which was certainly quite burdensome and they automatically consumed usury. With the Qardhul Hasan financing issued by BMT Maslahah to try to reduce the existence of this very choking renter and reduce the burden on people who need funds or capital for certain business activities. Qardhul Hasan financing is intended for residents or the community in order to improve the economy by BMT Maslahah Wagir Malang gave a loan in the form of money to develop its business. The target recipients of Qardhul Hasan Financing at BMT Maslahah Wagir Malang are market traders who save every day at BMT Maslahah. It is quite easy to apply for Qardhul Hasan financing,customer will be charge administrative fee and taawun fee. Tthe money will be put in taawun or insurance funds where the funds will be used to bail out or cover if there are customers who are unable to return the money they borrowed due to something that does not allow the customer to pay for it, such as fire, bankruptcy, divorce, and even death. For customers who return the loan more than the principal of the loan, the money will be considered as sadaqah and part of it will be included in Qardhul Hasan's income.

\subsection{Implementation of Islamic Corporate Social Responsibility (ICSR) at BMT Maslahah}

ICSR comes from a core principle in the Quran. The top three basic principles for implementing the Islamic Corporate Social Responsibility program are the human audience on earth, a responsibility to God, and the obligation to mankind to carry out better and stay away from prohibitions. According to [16], ICSR uses 6 (six) categories which are benchmarks for the implementation of social performance in Islamic banking or financial institutions which contain a compilation of standard items set by AAOIFI (Accounting and Auditing Organization for Islamic Financial Institutions). Head of the BMT Maslahah said that: 
"BMT Maslahah always tries to carry out our social responsibility, as our effort to maintain good relations with the community. Our existence in the community is expected to be useful by the vision and mission of BMT Maslahah "

Based on the above observations, BMT Maslahah has made efforts to carry out social responsibility during its existence in the community. The following is a detailed description of the application of Islamic Corporate Social Responsibility (ICSR) at BMT Maslahah, can be seen in Table1 below:

Table 1. Analysis of the Application of ICSR at BMT Maslahah Wagir Malang Branch

\begin{tabular}{|c|c|c|c|}
\hline No. & Indicator & $\begin{array}{l}\text { There } \\
\text { is }\end{array}$ & $\begin{array}{l}\text { There } \\
\text { is no }\end{array}$ \\
\hline 1. & $\begin{array}{l}\text { Finance and Investment } \\
\text { a. Disclosure of Riba Activities } \\
\text { b. Gharar's disclosure } \\
\text { c. Zakat } \\
\text { d. Accounts Receivable Write-off } \\
\text { e. Current value balance } \\
\text { f. Value-added statement }\end{array}$ & $\begin{array}{l}\sqrt{ } \\
\sqrt{ } \\
\sqrt{ } \\
\sqrt{ } \\
\sqrt{ }\end{array}$ & \\
\hline 2. & $\begin{array}{l}\text { Products and Services } \\
\text { a. Green Products } \\
\text { b. Halal Products } \\
\text { c. Product quality, } \\
\text { d. Customer complains. }\end{array}$ & $\sqrt{ }$ & $\sqrt{ }$ \\
\hline 3. & $\begin{array}{l}\text { Employees } \\
\text { a. Nature of Work, } \\
\text { b. Education and Training, } \\
\text { c. Equal Opportunity, } \\
\text { d. Employee Engagement, } \\
\text { e. Health and Safety, } \\
\text { f. Work environment, } \\
\text { g. Other Specialized Work. } \\
\text { h. Sponsoring Public Health }\end{array}$ & $\sqrt{ }$ & $\begin{array}{l}\sqrt{ } \\
\sqrt{ } \\
\sqrt{ } \\
\sqrt{ } \\
\sqrt{ } \\
\sqrt{ }\end{array}$ \\
\hline 4. & $\begin{array}{l}\text { Public } \\
\text { a. Sadaqah, } \\
\text { b. Waqf, } \\
\text { c. Qard Hasan, } \\
\text { d. Employee Volunteers, }\end{array}$ & $\begin{array}{l}\sqrt{ } \\
\sqrt{ } \\
\sqrt{ }\end{array}$ & \\
\hline
\end{tabular}




\begin{tabular}{|c|c|c|c|}
\hline & $\begin{array}{ll}\text { e. } & \text { Scholarship, } \\
\text { f. } & \text { Job Graduates, } \\
\text { g. } & \text { Underprivilage Community, } \\
\text { h. } & \text { Youth Development. }\end{array}$ & $\sqrt{ }$ & $\begin{array}{l}\sqrt{ } \\
\sqrt{ } \\
\sqrt{ }\end{array}$ \\
\hline 5. & $\begin{array}{l}\text { Environment } \\
\begin{array}{l}\text { a. Environmental Conservation, } \\
\text { b. Wildlife Threatened With Extinction, } \\
\text { c. Pollution, } \\
\text { d. Education, } \\
\text { e. Environmental Audit, } \\
\text { f. Policy. }\end{array}\end{array}$ & $\sqrt{ }$ & $\begin{array}{l}\sqrt{ } \\
\sqrt{ } \\
\sqrt{ } \\
\sqrt{ }\end{array}$ \\
\hline 6. & $\begin{array}{l}\text { Corporate governance } \\
\begin{array}{l}\text { a. Sharia Compliance Status, } \\
\text { b. Ownership Structure, } \\
\text { c. BOD } \\
\text { d. Declaration of Prohibited Activities, } \\
\text { e. Anti-Corruption Policy. }\end{array}\end{array}$ & $\sqrt{ }$ & $\begin{array}{l}\sqrt{ } \\
\sqrt{ } \\
\sqrt{ } \\
\sqrt{ }\end{array}$ \\
\hline
\end{tabular}


Based on the table above, it can be seen that from the 38 of ICSR items, BMT Maslahah have disclosed 31 item. As much as $31 \%$ o is expressed in the form of Finance and Investment, $12.5 \%$ in Products and Services, $12.5 \%$ in Employees, $25 \%$ in Community, $12.5 \%$ in Environment and $6.5 \%$ in Corporate Governance. In Islamic Corporate Social Responsibility Qardhul Hasan is included in the community category, which at BMT Maslahah Wagir has been implemented.

\subsection{Interpreting Qardhul Hasan between Business and ICSR}

Based on the observations, BMT Maslahah Wagir has made efforts to carry out social responsibility during of its existence in the community. The following is a description of the application ICSR at BMT Maslahah.

The background of the Qardhul Hasan financing at BMT Maslahah Wagir branch, which originated from the anxiety of the community who previously borrowed money from renter or loan sharks where people had to bear the burden of high interest which was certainly quite burdensome and they automatically consumed usury. With the Qardhul Hasan financing issued by BMT Maslahah, this is to try to reduce the existence of this very choking renter and reduce the burden on people who need funds or capital for certain business activities. The background of the Qardhul Hasan financing is to remove the Rentenir, where the community is charged with the interest system. BMT Maslahah in financing Qardhul Hasan prioritizes lending to market traders and local communities who have small shops/stalls. Based on interview with some of the customers of BMT Maslahah, that using Qordhul Hasan's products, admitting that this financing helps improve the economic welfare of the community.

Qardhul Hasan financing only has a percentage of $2 \%$ of other financing issued by BMT Maslahah Wagir Malang, so from these results, it can be concluded that this Qardhul Hasan financing was issued by BMT Maslahah Wagir Malang, not in a business context whose output is profit. instead, Qardhul Hasan's funding was issued solely for the Corporate Social Responsibility program. In terms of business, Qardhul Hasan financing disbursed by BMT Maslahah does not provide profit but is still implemented with a small proportion of the total financing carried out by BMT Maslahah. The proportion of only $2 \%$ can be interpreted as an effort by BMT to be able to carry out social responsibility to the community without disturbing their financial performance. even if there is bad credit on Qardhul Hasan financing, it will not have a significant effect on financial performance. That is why Qardhul Hasan financing can still be implemented at BMT Maslahah when conventional financial institutions are no longer implemented.

\section{CONCLUSIONS}

\subsection{Conclusions}

BMT Maslahah Wagir Malang has implemented the Qardhul Hasan program. Qardhul Hasan is carried out as part of the implementation ICSR. The implementation of the ICSR is carried out as a form of social responsibility for BMT Maslahah Wagir in his presence in the community. Overall, it can be concluded that the BMT Maslahah Wagir Malang branch has implemented the 6 categories defined by AAOIFI (Accounting and Auditing Organization for Islamic Financial Institutions) for the application of Islamic Corporate Social Responsibility, it can be seen that from 38 items, 16 items have been disclosed by BMT Maslahah.

Qardhul Hasan's financing at BMT Maslalah only has a percentage of $2 \%$ of other financing issued by BMT Maslahah Wagir Malang, so from these results, it can be concluded that Qardhul Hasan's financing was issued by BMT Maslahah Wagir Malang, not in a business context whose output is profit. / profit, but this Qardhul Hasan Financing was issued solely for the Corporate Social Responsibility program.

\subsection{Suggestion}

In connection with the importance of Islamic corporate social responsibility in the concept of corporate sustainability, researchers suggest that further research is carried out on the achievement of Islamic Corporate Social Responsibility. And based on the results of the interpretive analysis of this study, broadly speaking, this research is not final, but it still opens up opportunities for review. Here are some suggestions regarding this research: This research is only a small portrait that the researcher tries to put forward, about understanding the concept of Qardhul Hasan in business and Islamic corporate social responsibility, it would be nice if the next research was carried out in a broader scope.

\subsection{Research Limitations}

This research resulted from a certain methodology in which it is correct (scientifically) according to the methodological point of view concerned (methodological truth or relative truth), of course, this research has limitations. This study 
uses an interpretive paradigm in which the author is faced with considerations of ethical values and pragmatic benefits. There are data limitations due to limited time and access to informants. This study uses informants from both internal and external companies. Extracting information in this study has not covered all relevant stakeholders.

\section{AUTHOR'S CONTRIBUTION}

S.R.; conception of the work, data analysis and interpretation, critical revisiob of the article, final approcal of the version to be published

M.Z.; data collection, data analysis and interpretion; drafting the article

\section{ACKNOWLEDGMENT}

Researchers would like to thank the leadership and staff of BMT Maslahah Wagir who have helped, supported and provided data in this study.

\section{REFERENCES}

[1] Rosidah, "Analisis penerapan akad qardhul hasan menurut fatwa DSN MUI No. 19/DSNMUI/IV/2001: studi kasus di Kopontren Nurul Huda Al-Hikmah Cabang Blora Desa Kutukan.," 2018.

[2] Y. Falikhatun dan, "Menelisik Makna Pembiayaan Qardhul Hasan Dan Implementasinya Pada Perbankan Syariah Di Indonesia," 2016.

[3] R. Notowidagdo, Pengantar Kesejahteraan Sosial Berwawasan Iman dan Takwa. Jakarta: Amzah, 2016.

[4] T. Agus, "No Title," Optim. Implementasi Akad Qardhul Hasan bagi pembiayaan berorientasi Kesejaht. Sos. dalam Perbank. syariah di Indones., 2013.

[5] P. Alwina, "Implementasi Akad Qardhul Hasan dan Program Islamic Corporate Social Responsibility Dalam Meningkatkan Kesejahteraan Sosial (Studi Pada PBI Syariah Cabang Tanjung Karang)," UIN Raden Lantang, 2018.

[6] D. Muljono, Akuntansi Perbankan dan Lembaga Keuangan Syariah. Yogyakarta: Andi, 2015.

[7] Mustofa, "Analisis faktor-faktor yang mempengaruhi loyalitas nasabah bank syariah (Studi pada Bank Muamalat Tbk. Cabang
Gorontalo)," J. Al-Buhuts, vol. 12, no. 1 4867, 2016.

[8] S. R. Sjahdeini, Perbankan Syariah Produk Produk dan Aspek-Aspek Hukumnya. Jakarta: Kencana, 2014.

[9] I. Fahmi, Etika Bisnis Teori, Kasus, dan Solusi. Bandung: Alfabeta, 2013.

[10] S. Rochayatun, Corporate Social resonsibility: Menyusuri Jalan Meraih Sustainability Industri. 2017.

[11] Darmawati, "Corporate Social Responsibility Dalam Perspektif Islam,” Mazahib, 2014.

[12] J. Moleong, Lexy, Metodologi Penelitian Kualitatif, Edisi Revisi, Penerbit PT Remaja Rosdakarya,. Bandung: PT. Remania Rosdakarya, 2004.

[13] G. dan M. Burrell, Sociological Paradigms and Organisational Analysis. London: Heinemann, 1979.

[14] J. W. Creswell, "Penelitian Kualitatif \& Desain Riset," 2013.

[15] A. Kamayanti, "Metodologi Penelitian Kualitatif Akuntansi: Pengantar Religiositas Keilmuan," Yayasan Rumah Peneleh, 2016.

[16] Wardani, "Pengaruh Islamic Coorporate Social Disclosure Terhadap Reputasi Perusahaan dan Kinerja Perusahaan," Simp. Nas. Akunt. 18, 2015. 